\title{
ADVANCED ANALYSIS OF SELF-POTENTIAL DATA IN ORE DEPOSITS OF THE SOUTH CAUCASUS
}

\author{
Eppelbaum L.V. \\ Dept. of Geophysics, School of Earth Sciences, Faculty of Exact Sciences, Tel Aviv University \\ Ramat Aviv, Tel Aviv, 6997801, Israel: levap@tauex.tau.ac.il
}

Keywords: self-potential method, disturbances, quantitative analysis, complex physical-geological environments, self-potential moment, ore targets

Summary. Self-potential $(S P)$ method is one of the most non-expensive and unsophisticated geophysical methods. However, its application limits absence of reliable interpreting methodology, first for the complex geological-environmental conditions. The typical disturbances appearing in the SP method and ways for their removing (elimination) are discussed. Some brief review of the available interpretation methods indicates their insufficient effectivity, especially for complex environments. For the magnetic method of geophysical prospecting have been recently developed special quantitative procedures applicable under complicated environments (oblique polarization, rugged relief and unknown level of the normal field). Performed analysis allowed to revealing some essential common peculiarities of magnetic and $S P$ fields. These common aspects make it possible to apply the procedures developed in magnetic prospecting to $S P$ method. Besides the reliable determination of the depth of anomalous target, these methodologies enable to introduce corrections for the polarization effect and non-horizontal $S P$ observations. For classification of $S P$ anomalies is supposed to employ a new parameter - 'self-potential moment'. These procedures (improved modifications of characteristic point and tangent techniques) have been successfully tested both on SP models and in real situations in ore deposits in Turkey and Russia. Finally, interpretation procedures have been effectively applied at several ore deposits in the South Caucasus (Filizchai and Katsdag in Azerbaijan and Uchambo in Georgia). An effectiveness of multimodel approach with application of gravity, magnetic and $S P$ methods is demonstrated on the generalized physico-geological model of ore body of Filizchai type. The obtained results indicate the high practical importance of the developed methodology.

(C) 2019 Earth Science Division, Azerbaijan National Academy of Sciences. All rights reserved.

\section{Introduction}

The Self-Potential (SP) method is based on the study of natural electric field (with a period of up to $1 \mathrm{~Hz}$ ). The term "natural" here means that the field does not create by an external controlled source. Permanent fields arise in the course of redox, filtration, and diffusion-adsorption processes in a geological section. The registration of these fields is the goal of the SP method, and the geological interpretation of the parameters generating this field is the purpose of SP data interpreting. An oxidizing object (e.g., ore body) is a galvanic cell, the occurrence of which requires: (1) the contact of conductors with different types of conductivity (electronic and ionic), and (2) the difference in the redox conditions at different contact points of these conductors. An appearance of these conditions is usually impossible without underground water contact.
In the geological section, the conditions for the formation of a galvanic cell arise on bodies of minerals with electronic conductivity (sulfides, graphite, and coal-anthracite), if these bodies are in watersaturated rocks with ionic conductivity. The change in the redox conditions at the contact of the electronic conductor and the surrounding medium is associated with a decrease in the oxygen content with depth.

Application of SP observations (and all electric methods in geophysics as a whole) began with Fox's (1830) investigations at copper vein deposits in Cornwall (England). SP is prompt and comparatively simple geophysical method. Equipment for the SP method is one of the most non-expensive in the field geophysics (Table 1). Conventional equipment employed in the SP method consists of pair of nonpolarized electrodes, microVoltmeter, cable and $\mathrm{CuSO}_{4}$ solution (the latter is necessary for better contact of the electrode with the environment). 
Averaged prices of equipment for the most applied geophysical potential fields

\begin{tabular}{|l|c|c|c|c|}
\hline \multicolumn{1}{|c|}{ Method } & Gravity & Magnetic & Resistivity & Self-Potential \\
\hline $\begin{array}{l}\text { Price of } \\
\text { equipment, } \\
\text { US \$ }\end{array}$ & $65.000-110.000$ & $20.000-25.000$ & $30.000-60.000$ & $150-200$ \\
\hline
\end{tabular}

SP measurements are often applied for searching and localization of ore targets (e.g., Logn and Bolviken, 1974; Cowan et al., 1975; Semenov, 1980; Nayak, 1981; Corry, 1985; Babu and Rao, 1988; Lile, 1996; Bhattacharya et al., 2007; Mendonca, 2008; Eppelbaum and Khesin, 2002; Dmitriev, 2012; Alizadeh et al., 2017; Eppelbaum, 2019). The maximal depth of SP investigations under some favorable situations may reach the depth of $150-200 \mathrm{~m}$.

2. Self-potential data analysis: available disturbances and quantitative interpretation

\subsection{Different kinds of noise in SP observations}

Different disturbances appearing in the SP method are presented in block-scheme in Fig. 1. Some of these disturbances are considered in detail below.

\subsubsection{Electrode noise in SP method}

A conventional scheme of SP electrode is presented in Fig. 2. Despite the fact that electrode is called as "non-polarized", after some time it receives some polarization effect from the surrounding media. Taking into account that we measure value $\Delta U$ $\left(U_{1}-U_{2}\right)$, it is important to keep equivalent polarization on both electrodes. For checking this equivalent, the following procedure can be applied (of course, measurements in physical laboratory are more precise). Let us for the first electrode we have: $U_{1}+e_{1}$ ( $U_{1}$ is the first "geological" signal, and $e_{1}$ is the noise of accumulated in the first electrode). For second electrode we have correspondingly $U_{2}+e_{2}\left(U_{2}\right.$ is the second "geological" signal, and $e_{2}$ is the noise of accumulated in the second electrode). We measure the value (Semenov, 1980)

$$
\Delta U_{1}=\left(U_{1}+e_{1}\right)-\left(U_{2}+e_{2}\right) .
$$

If we will change electrodes by their places, we will receive

$$
\Delta U_{2}=\left(U_{1}+e_{2}\right)-\left(U_{2}+e_{1}\right)
$$

If we will calculate difference between $\Delta U_{1}$ and $\Delta U_{2}$, we will receive

$$
\begin{aligned}
& \partial U=\Delta U_{1}-\Delta U_{2}= \\
& =\left[U_{1}+e_{1}-U_{2}-e_{2}\right]-\left[U_{1}+e_{2}-U_{2}-e_{1}\right]=2\left(e_{1}-e_{2}\right)
\end{aligned}
$$

or

$$
\left(e_{1}-e_{2}\right)=\frac{\partial U}{2} \text {. }
$$

If the value $\left(e_{1}-e_{2}\right)$ is significant $(>3 \mathrm{mV})$, new ones must replace the noised electrodes.

\subsubsection{Temporal variations in SP method}

Parasnis (1986) has been carried out SP measurements in Akulla region (Sweden) seven times in the period of 1960-1967 years. These measurements show a good repeatability despite of the fact that they were conducted under different climatic conditions.

Accuracy $\varepsilon$ of SP measurements may be calculated by use of the following simple formula often employed in applied geophysics

$$
\varepsilon=\sqrt{\frac{\sum_{i=1}^{N}\left(\Delta U_{S P}^{\text {conven }}-\Delta U_{S P}^{\text {cont }}\right)^{2}}{N}},
$$

where $N$ is the total number of SP observations, 'conven' means conventional measurements, and 'cont' means control measurements. If the value of $\varepsilon \geq 5 \mathrm{mV}$, these results are usually rejected.

SP studies were carried out over the Chyragdere sulfur deposit (central Azerbaijan) for several years: 1930, 1937 and 1938 (Fig. 3). This figure shows that the mining works in the underground shaft strongly distort the observed SP field at the earth's surface (distance from the observation points to ore target consisted several tens of meters). This testifies to the tight correlation between mining processes and SP anomalies. It would be interesting to compare the volumes and contours of the mined ore with the SP isolines, separately for the abovementioned years, but over the past years, these documents have been lost. 


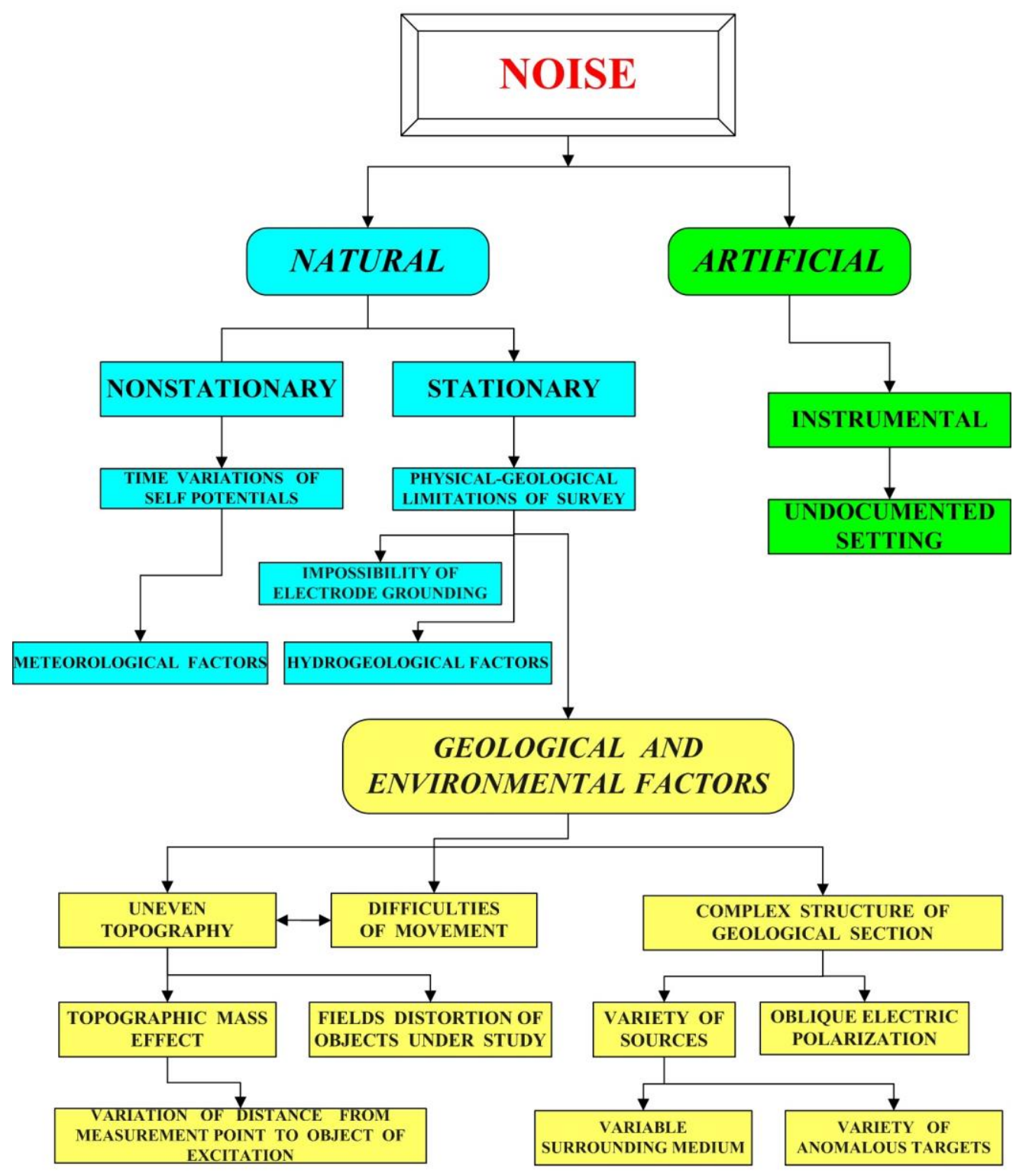

Fig. 1. General scheme of disturbances in SP method

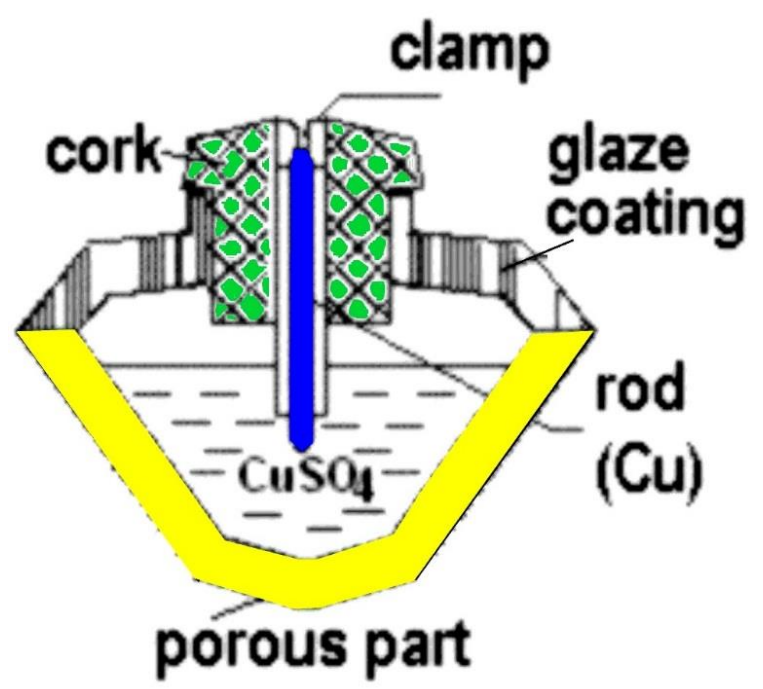

Fig. 2. Scheme of SP non-polarized electrode

\subsubsection{Terrain relief correction}

In the SP method, relief influence is two-fold. On the one hand, the rugged terrain relief caused by electromotive force can create negative SP anomalies over the positive landforms. Comparison of the SP graphs with topographic data usually makes it possible to identify anomalies of this type by the characteristic mirror image of the terrain in them.

From other side, as follows from the very detailed SP measurements of Ernstson and Schrerer (1986), at the inclined surface the SP field directly increases with relief form heightening (Fig. 3). So, it should take into account that in the field SP practice can occur as single effects and their combinations. In the last case for elimination of terrain relief influence, a correlation method developed in magnetic prospecting (Khesin et al., 1996) and VLF studies (Eppelbaum and Mishne, 2011) can be applied. Es- 
sence of the correlation method is following. The method utilizes for removing the terrain effect from the observed field $\Delta U_{\text {obser }}$ a linear least-squares relation (application of more complex equations of is also possible):

$$
\Delta U_{a p p r}=c+b h,
$$

where $h$ is the height of relief, $b$ is the angle coefficient, and $c$ is the free member.

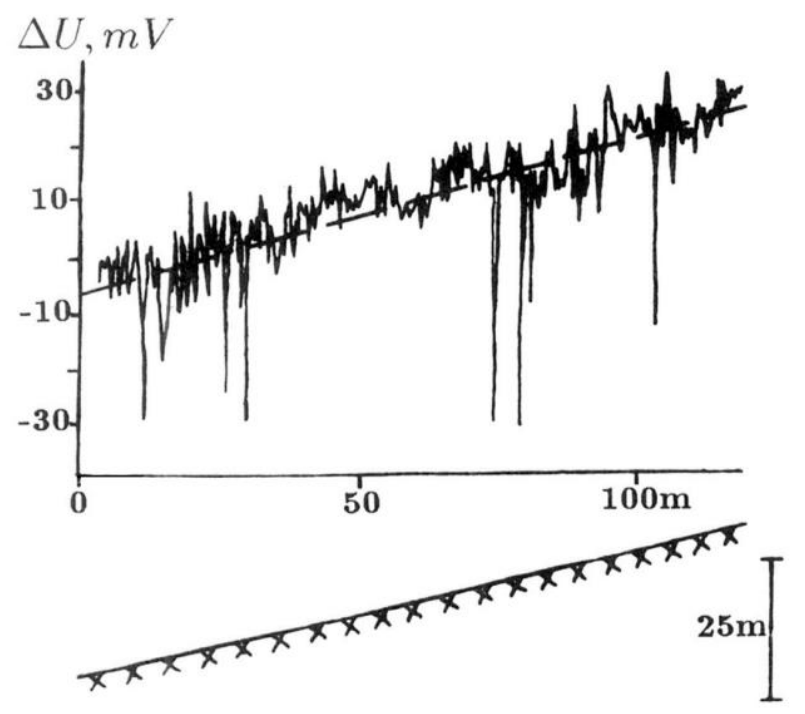

Fig. 3. SP observations at inclined relief (after Ernstson and Schrerer, 1986)

$\Delta U_{\text {appr }}$ approximates the observed field as a function of elevation $h$ (correlation field usually do not include the anomalous points) and then we receive plot (or calculations only) of the corrected (residual) field:

$$
\Delta U_{\text {corr }}=\Delta U_{o b s e r}-\Delta U_{a p p r} .
$$

\subsubsection{Net justification in areal observations}

Net justification of SP data is usually performed by the use of procedure identical to calculation of 'shift zero' in gravity prospecting (e.g., Telford et al., 1990).

\subsection{Some short overview of available methods of SP anomaly quantitative analysis}

The calculation of theoretical anomalies due to SP has long been based primarily on Petrovsky's (1928) well-known solution derived for a vertically polarized sphere (Zaborovsky, 1963). Later on, solutions for sheet-like bodies and inclined plates were obtained (Semenov, 1980; Tarkhov, 1980). The polarization vector was generally considered to be directed along the ore-body dip (along the longer axis of the conductive body).
To make quantitative interpretation of anomalies due to SP, a body with a simple geometrical shape approximates the anomaly source. Its parameters (i.e. the occurrence depth, the angle between the horizon and the direction of the polarization vector) are usually determined either graphically, using characteristic points of the anomaly plot (Semenov, 1980), or by trial-and-error, by visually comparing the anomaly to the set of master curves (graticules) (Tarkhov, 1980).

In the works of Zaborovsky (1963), Semenov (1980), and Murty and Haricharan (1984) the SP anomaly generated by a plate and recorded along the profile across its strike is calculated by the following formula:

$$
U(x)=\frac{j \rho}{2 \pi} \ln \frac{r_{1}^{2}}{r_{2}^{2}},
$$

where $j$ is the current per unit length, $\rho$ is the host medium resistivity, $r_{1}$ and $r_{2}$ are the distances from the plate ends to the measurement points.

However, the techniques suggested in the above works require the normal field level to be known. They are also unacceptable for rugged terrain relief.

Fitterman (1984) presented a method to calculate SP anomalies for field sources of an arbitrary shape. The method is based on numerical integration using Green's function. This approach is highly computer intensive and not sufficient accuracy.

There is a number of recent interpretation techniques based on minimizing the difference between an observed anomaly and a theoretical one. The minimization is achieved by sequential optimization of the interpretation parameters through computeraided iterations. These techniques are also complicated and time consuming.

A series of publications (Abdelrahman and Sharafeldin, 1997; Abdelrahman et al., 1997; El-Araby, 2004; Essa et al., 2008) provided a large number of methodological approaches. However, these approaches have not caused a quantitative jump in this field. Gobashy et al. (2019) proposed a method based on utilizing whale optimization algorithm as an effective heuristic solution to the inverse problem of SP field due to a 2D inclined bed. Realization of this algorithm in complex physical-geological conditions is under question.

Kilty (1984) published a paper which acknowledged the analogy between the current density of SP and magnetic induction. This author suggested interpreting SP anomalies based on conventional methods developed for magnetic prospecting. However, trivial methodologies are not acceptable for complex physical-geological conditions. A similar approach, but with improved interpretation methodology was 
proposed later by Khesin et al. (1996). New elaboration of the interpretation process was proposed in Eppelbaum and Khesin (2012). The present work is a final development of this approach.

\subsection{Some common aspects of magnetic and SP fields}

The magnetic field (for $\Delta T$ - when magnetic susceptibility is below 0.1 SI unit) is a potential field (e.g., Khesin et al., 1996) and is expressed as:

$$
\mathbf{U}_{\mathrm{a}}=-\operatorname{grad} V
$$

where $\mathbf{U}_{\mathbf{a}}$ is the anomalous magnetic field, and $V$ represents the magnetic potential. This field satisfies Poisson's equation.

SP polarization is brought about by the spontaneous manifestation of electric double layers on various geological formation contacts. The electric fields $\mathbf{E}$ of the electric double layer $l$ caused by natural polarization are defined as the gradient of a scalar potential $\Pi_{i}$ :

$$
\mathbf{E}_{\mathrm{SP}}=-\operatorname{grad} \Pi_{i}
$$

The potential $\Pi_{i}$ satisfies Laplace's equation everywhere outside the layer (Zhdanov and Keller, 1994).
Formulas describing potential character of magnetic (eq. (6)) and SP (eq. (7)) fields are identical ones. Let us consider analytical expressions for some interpreting models in magnetic and SP fields (Table 2$)$. The proportionality of analytical expressions (8) and (10), (9) and (11) for magnetic and SP fields in the table is obvious. It allows employing in SP data analysis advanced interpretation methods developed in magnetic prospecting (SP polarization vector is analogue of the vector of magnetization). It is supposed that the majority of interpretation methodologies developed for gravity and magnetic fields is applicable for the SP method. However, application of such procedures as upward and downward continuation for SP method is under question.

\subsection{Developed methodologies of advanced quan- titative analysis of SP anomalies}

The improved methods for SP anomaly analysis include characteristic point, tangent and areal methods (these methods are described in detail in the publications suggested to magnetic anomaly interpretation (e.g., Khesin et al., 1996; Eppelbaum et al., 2000, 2001; Eppelbaum and Mishne, 2011; Eppelbaum and Khesin, 2012; Eppelbaum, 2015). Formulas for interpretation SP anomalies by the use of characteristic point method are presented in Table 3. Fig. 5-7, 9 and 10 display some peculiarities of characteristic point and tangent methods application.

Table 2

Comparison of analytical expressions for magnetic and SP fields

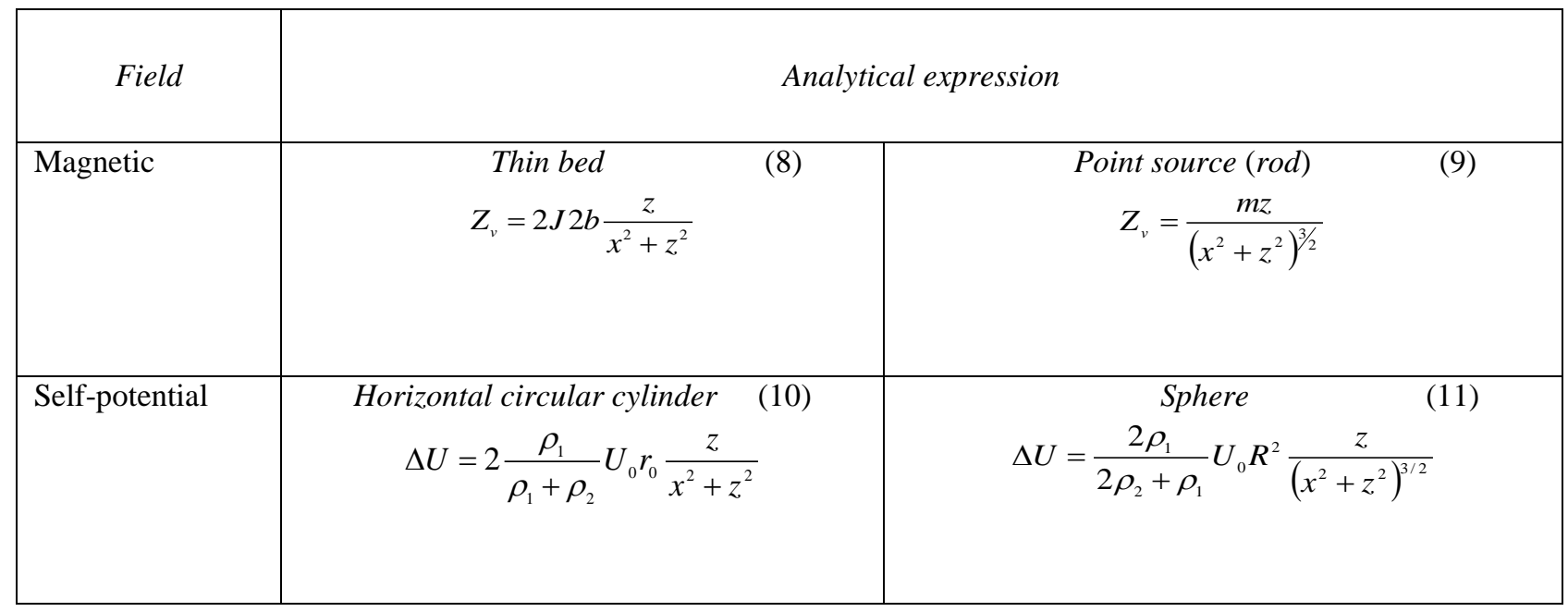

Here $Z_{v}$ is the vertical magnetic field component at vertical magnetization; $J$ is the magnetization; $b$ is the horizontal semi-thickness of $T B$ (thin bed); $m$ is the magnetic mass; $\rho_{1}$ is the host medium resistivity; $\rho_{2}$ is the anomalous object (HCC (horizontal circular cylinder) or sphere) resistivity; $U_{0}$ is the potential jump at the source body/host medium interface; $r_{0}$ is the polarized cylinder radius; $R$ is the sphere radius; $x$ is the current coordinate; $z$ is the depth of the upper $D T B$ edge (HCC or sphere center) occurrence. 
Formulae for quantitative interpretation of magnetic anomalies over anomalous bodies approximated by thin bed and a horizontal circular cylinder using the improved characteristic point method (after Eppelbaum and Mishne (2011), with modifications)

\begin{tabular}{|c|c|c|c|}
\hline \multirow{2}{*}{$\begin{array}{l}\text { Parameters } \\
\text { to be de- } \\
\text { termined }\end{array}$} & $\begin{array}{l}\text { Parameters used for anoma- } \\
\text { lies resulting } \\
\text { from models }\end{array}$ & \multicolumn{2}{|c|}{$\begin{array}{l}\text { Formulae to calculate parameters in terms of the anomalies } \\
\text { resulting from models }\end{array}$} \\
\hline & \begin{tabular}{|l|l} 
Thin bed & Cylinder
\end{tabular} & Thin bed & Cylinder \\
\hline $\begin{array}{l}\text { Generalized } \\
\text { angle } \theta\end{array}$ & $\begin{array}{lr}d_{1}, d_{2} & d_{1 r} \\
d_{1}, d_{5} & d_{1 r}, d_{5} \\
d_{1}=x_{\min }-x_{\max } \\
d_{2}=\left(x_{0.5 \Delta U_{A}}\right)_{r}-\left(x_{0.5 \Delta U_{A}}\right)_{l} \\
d_{5}=x_{r}-x_{l} \\
\Delta U_{A}=\Delta U_{\max }-\Delta U_{\min }\end{array}$ & $\begin{aligned} \tan (\theta) & =d_{2} / d_{1} \\
\sin (\theta / 3) & =d_{5} / \sqrt{3} d_{1}\end{aligned}$ & $\begin{array}{c}\cot (\theta / 3)=\sqrt{3} \frac{\left(d_{1 l}+d_{1 r}\right)}{\left(d_{1 l}-d_{1 r}\right)} \\
\frac{d_{5}}{d_{1 r}}=\frac{\sqrt{2} \cos (\theta / 2)-1}{\sqrt{3} \cos \left(60^{\circ}+\theta / 3\right)}\end{array}$ \\
\hline Depth $h_{0}, h_{c}$ & $\begin{array}{c}d_{1}, d_{2}, \theta \quad d_{1 r}, \theta \\
d_{5}, \theta\end{array}$ & $\begin{array}{c}h_{0}=\sqrt{d_{1} d_{2}} / k_{1,2}, \\
\text { where } k_{1,2} \\
=\frac{2}{\sqrt{\sin \theta \cos \theta}} \\
h \\
k_{5}=2 \sqrt{3} \frac{\sin (\theta / 3)}{\sin \theta}\end{array}$ & $\begin{array}{c}h_{c}=d_{1 r} / k_{1 r}, \text { where } k_{1 r} \\
=2 \sqrt{3} \frac{\cos \left(60^{\circ}+\theta / 3\right)}{\cos \theta} \\
h_{c}=\frac{d_{1 r}}{d_{1 r}-d_{1 r}(\Delta h)} \Delta h \\
k_{5}, \text { where } \\
k_{5}=2 \sqrt{2} \frac{\cos (\theta / 2)-1}{\cos \theta}\end{array}$ \\
\hline $\begin{array}{l}\text { Horizontal } \\
\text { displacement } \\
x_{0}, x_{c}\end{array}$ & $\begin{array}{c}h, \theta, x_{\max }, x_{\min , r} \\
\left(x_{0.5 \Delta U_{A}}\right)_{r} \\
\left(x_{0.5 \Delta U_{A}}\right)_{l}\end{array}$ & $\begin{array}{l}x_{0}=0.5\left(x_{\max }+x_{\min , r}\right)- \\
h \cot \theta \\
x_{0}=h \tan \left(\frac{\theta}{2}\right)\end{array}$ & $\begin{array}{l}x_{c}=0.5\left(x_{\max }+x_{\min , r}\right)- \\
h_{c} \frac{\sin \left(60^{\circ}+\theta / 3\right)}{\cos \theta}+h_{c} \tan \theta \\
x_{c}=0.5\left(x_{r}+x_{l}\right)+h_{c} \tan \theta- \\
\sqrt{2} h_{c} \frac{\sin (\theta / 2)}{\cos \theta}\end{array}$ \\
\hline $\begin{array}{l}\text { Normal } \\
\text { background } \\
\Delta U_{\text {backgr }}\end{array}$ & $\Delta U_{\min }, \Delta U_{A}, \theta$ & \multicolumn{2}{|c|}{$\Delta U_{\text {backr }}=\Delta U_{\text {min }}+\Delta U_{A} \frac{k_{0}}{1+k_{0}}$, where } \\
\hline $\begin{array}{l}\text { Indices "o" an } \\
\text { and } h_{c} \text { are the } \\
\text { measurements }\end{array}$ & "c" designate the thin seam al & $\begin{array}{l}\text { orizontal circular cylind } \\
\text { nd center of the } H C C \text {, re } \\
\text { over the earth's surface }\end{array}$ & $\begin{array}{l}\text { models, respectively. Values } h \\
\text { y. Parameter } \Delta h \text { designates }\end{array}$ \\
\hline
\end{tabular}

When anomalies are observed on an inclined profile, the obtained parameters characterize a fictitious body. The transition from fictitious body parameters to those of the real body is done by applying the following expressions (the subscript " $r$ " stands for a parameter of the real body):

$$
\left\{\begin{array}{l}
h_{r}=h+x_{\mathrm{o}} \tan \omega_{\mathrm{o}} \\
x_{r}=-h \tan \omega_{\mathrm{o}}+x_{\mathrm{o}}
\end{array}\right\},
$$

where $h$ is the depth of the body upper edge occurrence (or HCC center), $x_{0}$ is the shifting of the anomaly maximum from the projection of the center of the disturbing body to the earth's surface (caused by oblique magnetization), and $\omega_{0}$ is the angle of the terrain relief inclination. 
Nomenclature of variables applied for quantitative analysis of SP anomalies due to model of thin bed and horizontal circular cylinder (see Table 3)

\begin{tabular}{|c|c|}
\hline Variable & Description \\
\hline$\theta$ & $\begin{array}{l}\text { Generalized angle reflecting the degree of SP anomaly asymmetry as a function relation of an } \\
\text { anomalous body depth of occurrence, geometric form, value of polarization }\end{array}$ \\
\hline$x_{0}$ & $\begin{array}{l}\text { Horizontal displacement of projection of the middle of the upper edge of thin bed to the earth's } \\
\text { surface due to oblique polarization }\end{array}$ \\
\hline$x_{\mathrm{c}}$ & $\begin{array}{l}\text { Horizontal displacement of projection of the center of the } H C C \text { to the earth's surface due to } \\
\text { oblique polarization }\end{array}$ \\
\hline$h_{0}$ & Depth to the upper edge of thin bed \\
\hline$h_{\mathrm{c}}$ & Depth to the center of $H C C$ \\
\hline$\Delta U_{\max }$ & Maximum value of SP anomaly \\
\hline$\Delta U_{\min }$ & Minimum value of SP anomaly \\
\hline$\Delta U_{\mathrm{A}}$ & Total amplitude of SP anomaly \\
\hline$d_{1}$ & Difference of extremum abscissae for thin bed \\
\hline$d_{1 \mathrm{r}}$ & Difference of extremum abscissae for $H C C$ \\
\hline$d_{2}$ & Difference of semiamplitude point abscissae \\
\hline$d_{5}$ & Difference of inflection point abscissae \\
\hline$x_{r}$ & Right inflection abscissae point \\
\hline$x_{l}$ & Left inflection abscissae point \\
\hline$\Delta U_{\text {backr }}$ & Normal background level of SP anomaly \\
\hline
\end{tabular}
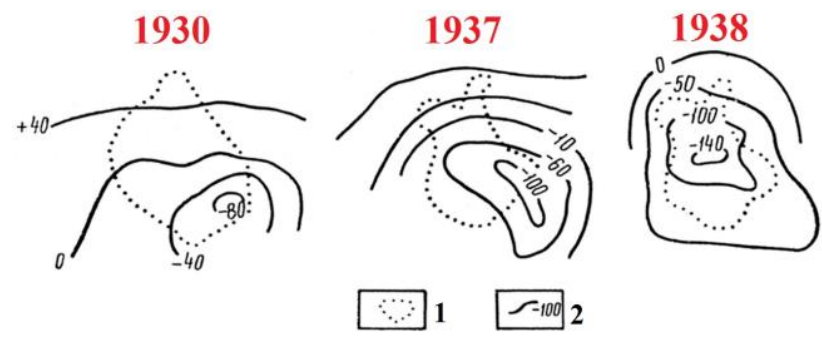

Fig. 4. Displacement of self-potential isolines during exploitation of the new shaft of Chiragdere sulfur deposit (Lesser Caucasus) (after Eppelbaum and Khesin, 2012, wirh modifications). (1) stock contour, (2) isolines of self-potential field (in milliVolts)

The inclination angle of the natural polarization vector $\phi_{p}$ is calculated from the expression

$$
\phi_{p}=90^{\circ}-\theta
$$

on an inclined relief

$$
\phi_{p}, s=90^{\circ}-\theta+\omega_{0}
$$

where $\omega_{0}$ is the inclination angle of the observation profile $\left(\omega_{0}>0\right.$ when the inclination is toward the positive direction of the $x$-axis).

Besides the geometric parameters of an object, for example, the self-potential moment for thin bed model can be also determined:

$$
M_{\Delta U}=\frac{1}{2} \Delta U_{a} h_{0}
$$

where $\Delta U_{\mathrm{a}}$ is the amplitude of SP anomaly (in $\mathrm{mV}$ ), $h_{0}$ is the occurrence depth of the anomalous target (in meters). The self-potential moment, by analogy with the magnetic field analysis, can be used to classify SP anomalies.

For observation in inclined profile it is possible to switch to the real source parameters as follows:

$$
M_{\Delta U, r}=M_{\Delta U a} \cos \omega_{0},
$$

where "r" means "real" and "f" - "fictitious" parameter. 


\section{Quantitative analysis of SP anomalies in ore deposits}

Thus, the developed interpretation system in the SP method is applicable for the complex physicalgeological conditions: oblique polarization, inclined relief and unknown level of the SP normal field. First of all these methods were successfully tested on the SP anomaly models from Semenov (1980) and Göktürkler and Balkaya (2012). After this, these methods were applied on SP data observed in real ore targets.

\subsection{Some examples of SP quantitative analysis in ore deposits}

3.1.1. Quantitative interpretation of SP anomaly over pyrite-sulphide body in the Sariyer area (near Istanbul, Turkey)

Yüngül (1954) published the results of the survey in the Sariyer area (Istanbul). Since this time many authors reproduced this example in the various reviews and books, however without any quantitative interpretation (e.g., Parasnis, 1986). The performed interpretation indicates that the obtained position of $H C C$ center is in the line with geometrical and physical parameters of the sulphidepyrite ore body (Fig. 5). Here and in some other figures displayed parameters $d_{3}$ and $d_{4}$ relate to the improved tangent method (this method is described in detail, for instance, in Eppelbaum et al. (2001)).

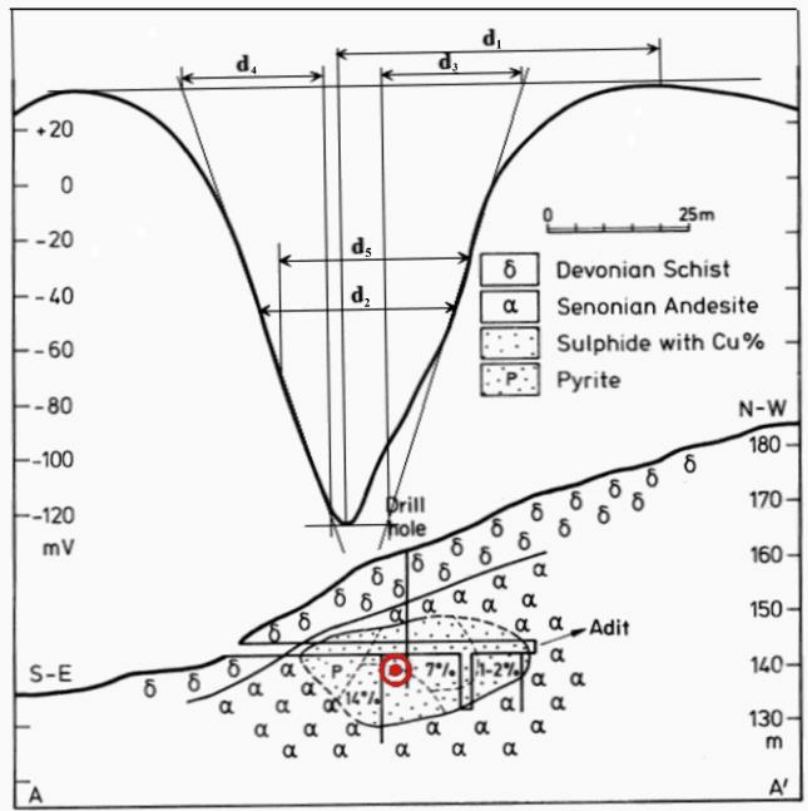

Fig. 5. Quantitative interpretation of $S P$ anomaly by the characteristic point and tangent methods in the Sariyer area, Turkey. The "๑" symbol marks the obtained position of the ore body center (approximated by a HCC). Observed SP curve and geological section are taken from Yüngül (1954) (interpretation after Eppelbaum and Khesin, 2002)

\subsubsection{Quantitative interpretation of SP anomaly over polymetallic body (Russia)}

Figure 6 displays results of SP anomaly quantitative interpretation using characteristic points and tangent methods. The interpretation results, as can easily see from Fig. 6, have a good agreement with location of ore body. Self-potential moment here is $M_{\Delta U}=\frac{1}{2} 60 \mathrm{mV} \cdot 6.5 \mathrm{~m}=195 \mathrm{mV} \cdot \mathrm{m}$.
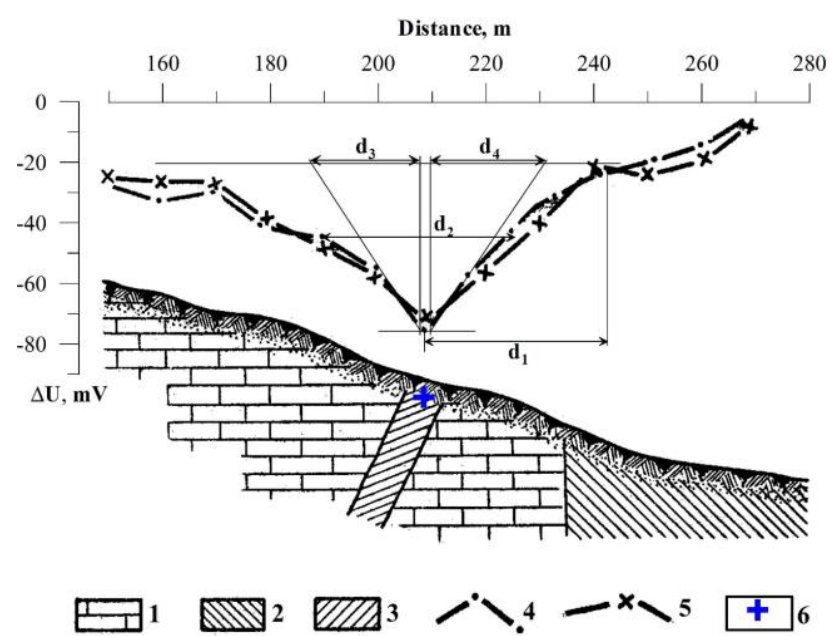

Fig. 6. Quantitative interpretation of $S P$ anomaly over polymetallic body. Observed SP curve and geological section are taken from Zaborovsky (1963)

\subsection{Ore deposits of the southern slope of the Greater Caucasus}

Copper-polymetallic deposits of the southern slope of the Greater Caucasus usually are favorable targets for SP method application (Eppelbaum and Khesin, 2002). However, in the Katekh polymetallic deposit (which is situated nearly the Filizchai and Katsdag deposits) SP observations oscillate about zero and could not provide useful information about the buried targets. This can be explained by the peculiarities of mineralogical composition of ores: a fairly large lead content impedes the normal course of oxidation-reduction reaction necessary for triggering intense SP anomalies (Eppelbaum and Khesin, 2004).

\subsubsection{Area of Filizchai polymetallic deposit}

A very intensive SP anomaly (almost $500 \mathrm{mV}$ ) was observed in the Filizchai copper-polymetallic field (southern slope of the Greater Caucasus, Azerbaijan) under conditions of very complex terrain relief (Fig. 7). Results of interpretation show significant difference of position of the upper edge of anomalous body calculated without influence of rugged terrain relief (blue circle) and after this influence calculation (red circle). Calculated SP moment 
consists $M_{\Delta U}=\frac{1}{2} 440 \mathrm{mV} \cdot 90 \mathrm{~m}=19800 \mathrm{mV} \cdot \mathrm{m}$. Interestingly to note that this SP moment exceeds SP moment calculated for the polymetallic body from the previous example by more than 100 times. This fact indicates a large capacity of studied ore target in the Filizchai deposit.

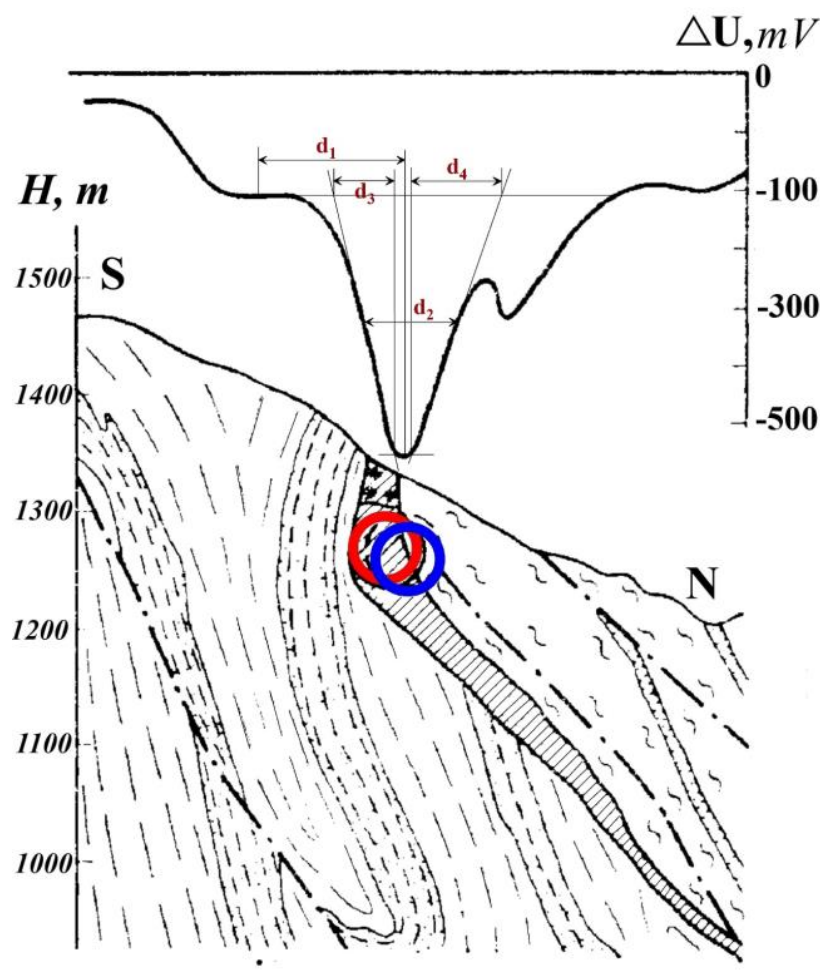

Fig. 7. Results of quantitative interpretation of $S P$ anomalies in the area of Filizchay copper-polymetallic deposit on the southern slope of the Greater Caucasus (Azerbaijan) (modified after Eppelbaum and Khesin (2012)). See captions in Figure 8.

\subsubsection{Area of Katsdag polymetallic deposit}

Three SP anomalies were successfully interpreted in the Katsdag copper-polymetallic deposit (southern slope of the Greater Caucasus, Azerbaijan) under conditions of rugged terrain relief (Fig. 8). Anomaly 1 and 2 are intensive, but anomaly 3 is comparatively small. Here also is essential difference between the quantitative results of SP anomalies analysis calculated without and with calculation for rugged relief influence. The SP moment calculated for anomaly 1 is $M_{\Delta U}=\frac{1}{2} 180 \mathrm{mV} \cdot 20 \mathrm{~m}=3600 \mathrm{mV} \cdot \mathrm{m}$.

\subsection{Ore deposits of the Lesser Caucasus}

Unfortunately, many SP observations in ore deposits of the Lesser Caucasus were lost or undocumented. Earlier temporal variations of SP data over the Chyragdere sulfur deposit (Lesser Caucasus, Azerbaijan), as function of the deposit exploitation were considered (see Fig. 4). Below is presented an example of quantitative analysis of SP measurements over polymetallic body in the Lesser Caucasus (southern Georgia).

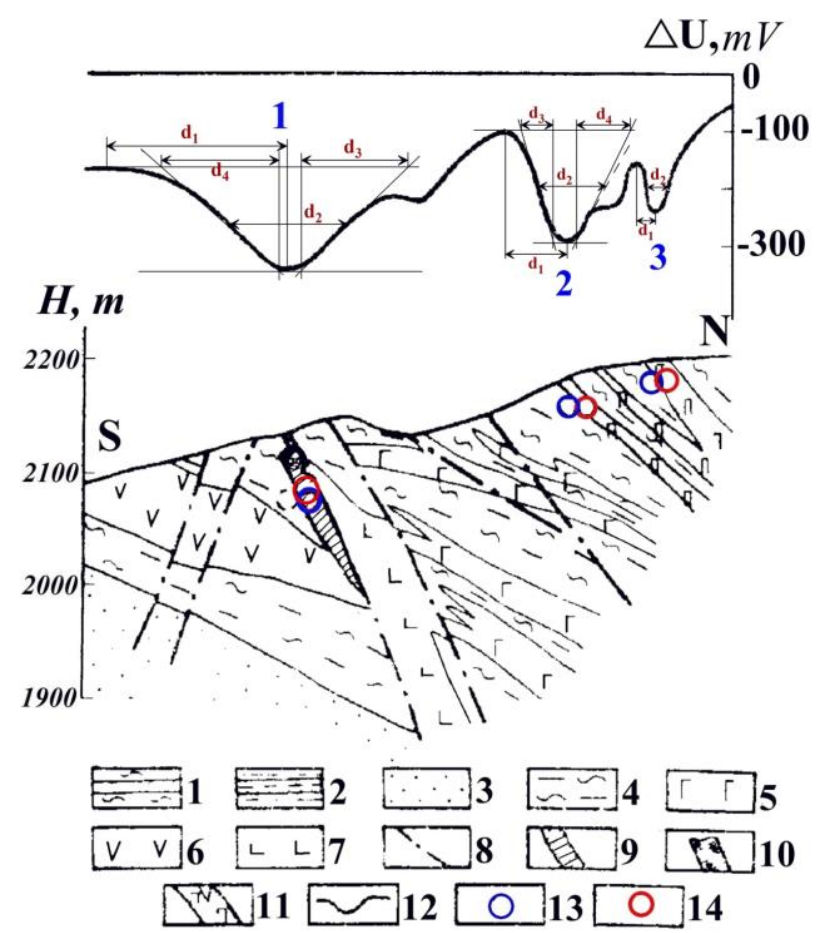

Fig. 8. Results of quantitative interpretation of $S P$ anomalies in the area of Katsdagh copper-polymetallic deposits on the southern slope of the Greater Caucasus (Azerbaijan).

(1) interbedding of sands and clay schists, (2) clay schists with the flysh packages, (3) clay sandstone; (4) sand-clay schists; (5) diabases, gabbro-diabases and diabasic porphyrites; (6) andesites and andesite-porphyrites; (7) dacitic porphyrites; (8) faults; (9) massive ore of pyrite-polymetallic composition; (10) oxidized ore; (11) zones of brecciation, crush and boudinage with lean pyrite-polymetallic ore; (12) SP curves; location of anomalous source: (13) without calculation of inclined relief influence, (14) after introducing correction for relief

\subsubsection{Uchambo ore field (Georgia)}

Fig. 9 depicts the position of the HCC center (characteristic point method was applied), which evidently fixes the undrilled edge of a flat-lying orebody in the Uchambo polymetallic deposit (southern Georgia).

\subsection{SP as a component of multimodel approach}

Multimodel approach to geophysical data analysis may be illustrated on example of quantitative analysis of different geophysical data. Quantitative interpretation is traditionally oriented to a single model for buried objects identification. In the case of the existence of several hypotheses relating to the parameters of the body causing the disturbance (i.e., the buried object) usually only one model was selected roughly presenting the object in the domain 
$\Re_{x}$ of $k$-dimensional space of the physical-geological factors. At the same time, many geological features are strongly disturbed by various geological processes (erosion, tectonic-geodynamic activity, metamorphism, etc.).

Additional noise affecting interpretation includes rugged terrain relief, anisotropy (polarization) of geological objects and heterogeneous host medium. As a consequence, response function $\Psi_{i}-$ geophysical field - may ambiguously represent the studied targets. Therefore, domain $\mathfrak{R}_{x}$ may be divided into several subdomains $\mathfrak{R}_{1}, \mathfrak{R}_{2}, \ldots, \mathfrak{R}_{m}$ and in each of them a single model will dominate (Eppelbaum, 1987). In such way we could develop $m$ physicalgeological models of the same target, each corrected for separate subdomains $\mathfrak{R}_{1}, \mathfrak{R}_{2}, \ldots, \mathfrak{R}_{m}$.

The multimodel approach can also be applied at varying levels of geophysical field observations. Hence, different explanatory models may be used in the process of quantitative interpretation. Integrating several response functions $\Gamma_{i}$, yields a more accurate and reliable physical-geological model of the buried target.

Rapid methods of quantitative interpretation make it possible to determine the following parameters: position of the mass center of the anomalyforming body by the plot of $\Delta g$ (Fig. 10a); position of the upper edge by the plot of $\Delta Z$ (Fig. 10b); position of the horizontal circular cylinder's center in the upper portion of the ore-body at the ground water level by the plot of self-potential (Fig. 10c). The specific models thus obtained reflect the contrasting character of the physical properties of the target and the host medium. They allow a fairly exhaustive description of the geometric parameters of the target. Combining these three models (we have two response functions $\Gamma_{1}, \Gamma_{2}$ and $\Gamma_{3}$ from the subdomains $\mathfrak{R}_{1}, \mathfrak{R}_{2}$ and $\mathfrak{R}_{3}$ ), yields a combined model of the anomalous body (Figure 10d), which is in a good agreement with the initial (prescribed) model.

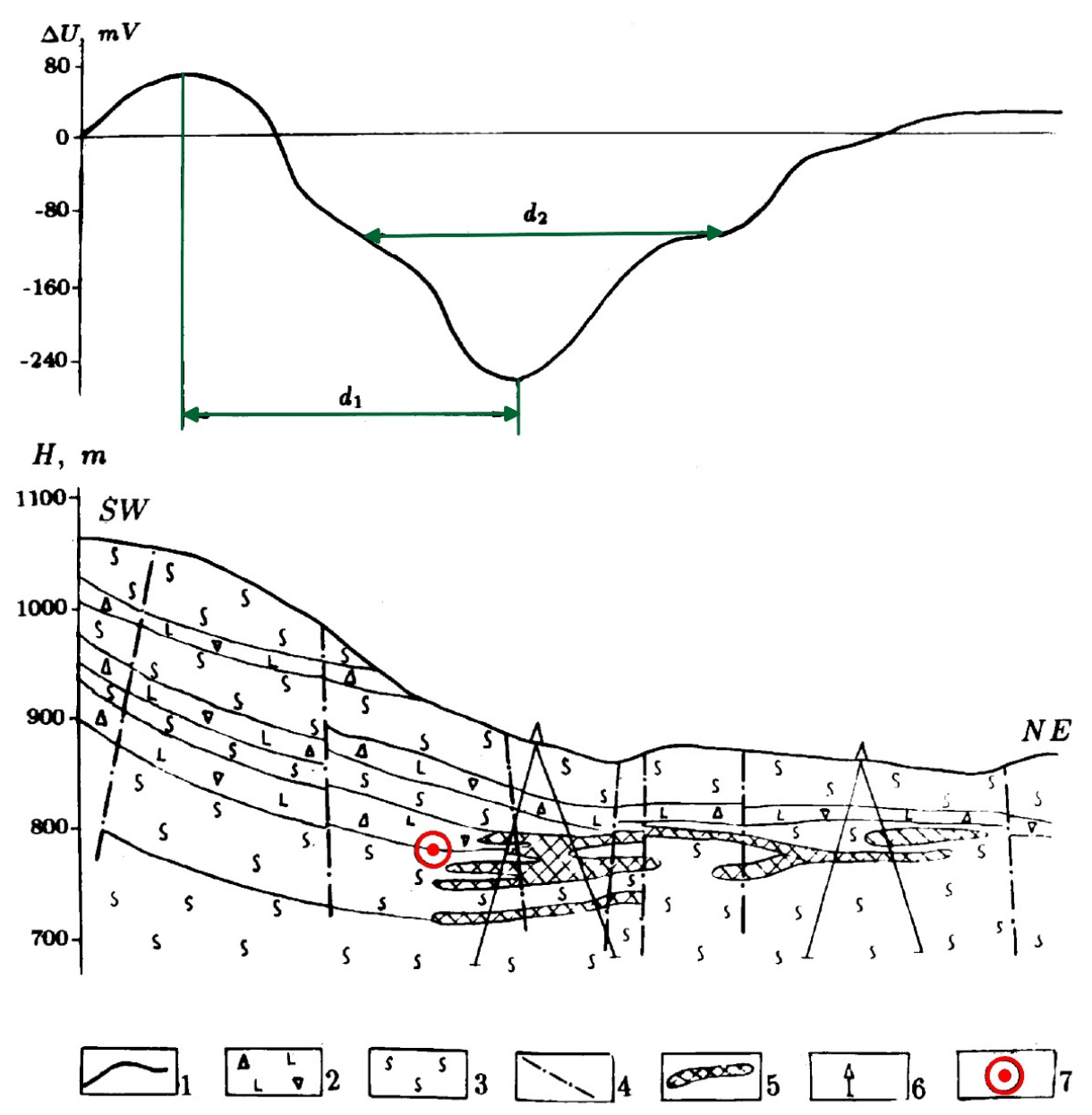

Fig. 9. Interpretation of SP anomaly by the method of characteristic points in the area of the Uchambo ore field of the Adjar group of copper-polymetallic deposits (Georgia, Lesser Caucasus)

(1) SP observed values; (2) heteroclastic tuff breccia and their tuffs; (3) cover trachyandesite-basalts with pyroclastic interbeds; (4) disjunctive dislocations; (5) zones of increased mineralization; (6) drilled wells; (7) location of HCC center according to the interpretation results ((1-6) from from Bukhnikashvili et al. (1974), (7) after Eppelbaum and Khesin (2002), with modifications 
a
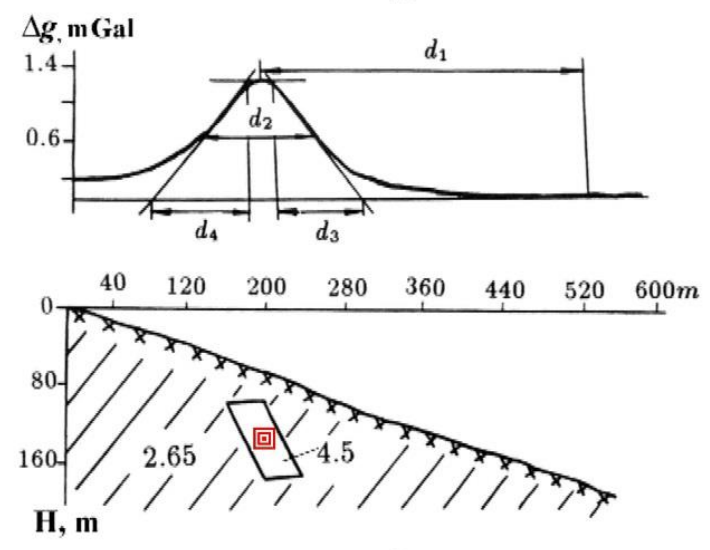

b c
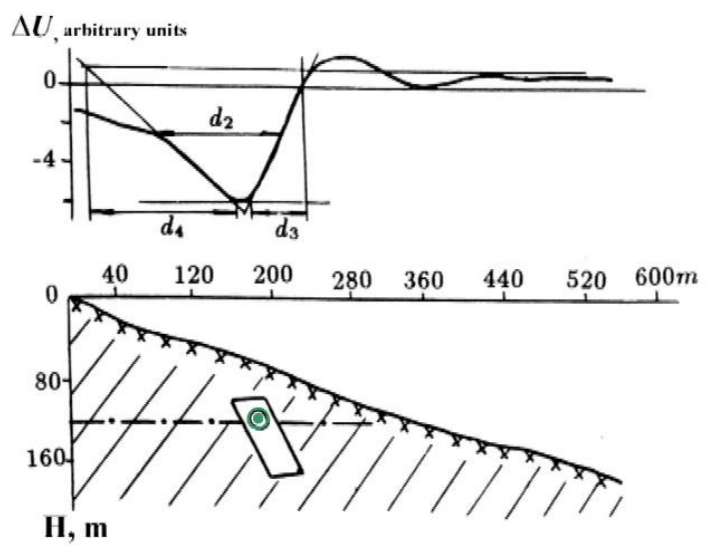
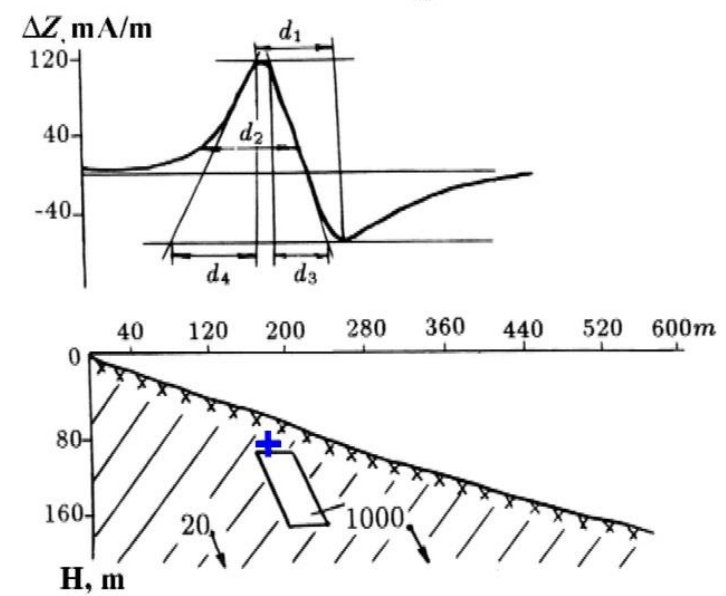

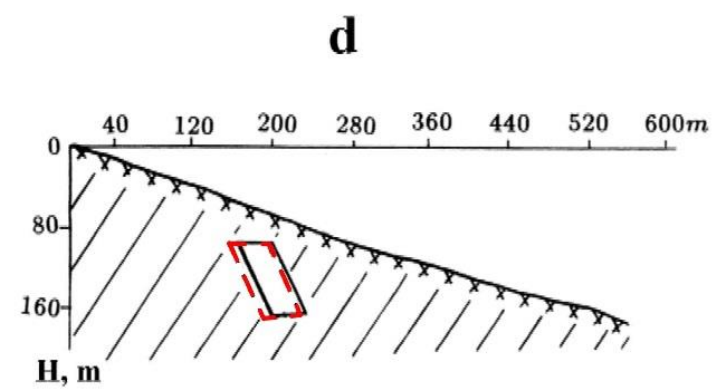

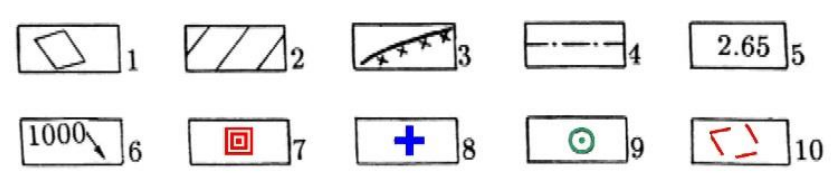

Fig. 10. Combined interpretation of the model fields $\Delta g, \Delta Z$ and $\Delta U_{\mathrm{SP}}$ due to deposits of the Filizchai type under different approximation of the anomalous body: $(\mathbf{a}, \mathbf{b}, \mathbf{c})$ results of the model fields rapid interpretation, $(\mathbf{d})$ anomalous object according to the integrated interpretation results.

(1) anomalous body; (2) host medium; (3) topography; (4) position of the ground water level; physical properties: (5) density $\left(\mathrm{g} / \mathrm{cm}^{3}\right),(6)$ magnetization $(\mathrm{mA} / \mathrm{m})$; (7) mass center (of a circular horizontal cylinder) by $\Delta g$ plot; (8) mid-point of the upper edge of an inclined thin bed by $\Delta Z$ plot; (9) position of the center of HCC inscribed into the upper portion of the anomalous body at the ground water level by $\Delta U_{\mathrm{SP}}$ plot; (10) contour of the anomalous body obtained from the results of integrated quantitative interpretation

\section{Other possible applications of SP method in Azerbaijan and Caucasus}

SP method can be effectively applied for searching and localization of numerous archaeological targets (some examples of such SP investigations are given in Eppelbaum et al., 2001, 2003; Drahor, 2004; Shevnin et al., 2014; Eppelbaum, 2019). Other SP application is revealing some dangerous environmental phenomena (karst cavities, faults, rockslides) (e.g., Quarto and Schiavone, 1996; Eppelbaum, 2007; Jardani et al., 2007; Oliveti and Cardarelli, 2019) and localization of corrosion in buried oil, gas and water pipes (e.g., Castermant el., 2008; Rittgers et al., 2013; Oliveti and Kardarelli, 2019). Finally, SP studies often successfully employed for revealing underground water infiltration (e.g., Semenov, 1980; Birch, 1998; Shevnin, 2018).

\section{Conclusions}

The disturbances complicated SP observations in ore targets are analyzed in detail. The proved common aspects between the magnetic and selfpotential fields enable to apply for interpretation of SP anomalies the modern interpreting procedures 
developed for complicated environments in magnetic prospecting (oblique magnetization (polarization), inclined topography and an unknown level of the normal field). The improved characteristic point method of quantitative interpretation is described in detail. Testing these procedures on the well-studied ore objects (Turkey and Russia) and in ore deposits in the South Caucasus confirms an effectiveness of this technology. This interpretation methodology can also be employed for searching archaeological

\section{REFERENCES}

Abdelrahman E.M., El-Araby T.M., Ammar A.A., Hassanein H.I. A least-squares approach to shape determination from selfpotential anomalies. Pure and Applied Geophysics, V. 150, 1997, pp. 121-128. DOI: 10.1007/s000240050067.

Abdelrahman E.M., Sharafeldin S.M. A least squares approach to depth determination from residual self-potential anomalies caused by horizontal cylinders and spheres. Geophysics, V. 62, 1997, pp. 44-48.

Alizadeh A.M., Guliyev I.S., Kadirov F.A., Eppelbaum L.V. Geosciences in Azerbaijan. Volume II: Economic Minerals and Applied Geophysics. Springer. Heidelberg - N.Y., 2017, 340 p.

Babu R.H.V., Rao A.D. Inversion of self-potential anomalies in mineral exploration. Computers \& Geosciences, V. 14, No. 3, 1988, pp. 377-387.

Birch F. Imaging the water table by filtering self-potential profiles. Ground Water, V. 36, No. 5, 1998, pp. 779-782.

Bhattacharya B.B., Shalivakhan J.A., Bera A. Threedimensional probability tomography of self-potential anomalies of graphite and sulphide mineralization in Orissa and Rajasthan, India. First Break, V. 5, 2007, pp. 223-230.

Bukhnikashvili A.V., Kebuladze V.V., Tabagua G.G., Dzhashi G.G., Gugunava G.E., Tatishvili O.V., Gogua R.A. Geophysical Exploration of Adjar Group of Copper-Polymetallic Deposits. Metsniereba. Tbilisi, 1974, 199 p. (in Russian).

Castermant J., Mendonca C., Revil A., Trolard F., Bourrie G., Linde N. Redox potential distribution inferred from selfpotential measurements associated with the corrosion of a burden metallic body. Geophysical Prospecting, V. 56, No. 2, 2008, pp. 269-282.

Corry C.E. Spontaneous polarization associated with porphyry sulfide mineralization. Geophysics, V. 50, No. 6, 1985, pp. 1020-1034.

Cowan D.R., Allchurch P.D., Omnes G. An integrated geoelectrical survey on the Nangaroo copper-zinc prospect, near Leonora, Western Australia. Geoexploration, V. 13, 1975, pp. 77-98.

Dmitriev A.N. Direct and inverse SP modeling on the basis of exact model of self-potential field nature. Geology and Geophysics, V. 53, No. 6, 2012, pp. 797-812.

Drahor M.G. Application of the self-potential method to archaeological prospection: some case histories. Archaeological Prospection, V. 11, 2004, pp. 77-105.

El-Araby H.M. A new method for complete quantitative interpretation of self-potential anomalies. Journal of Applied Geophysics, V. 55, 2004, pp. 211-224.

Eppelbaum L.V. Multimodel approach to the study of geophysical targets. Deposited by VINITI, USSR Academy of Sciences, No. 7842-87, 1987, pp. 1-10 (in Russian).

Eppelbaum L.V. Revealing of subterranean karst using modern analysis of potential and quasi-potential fields. Proceedings targets, localization of hidden karst cavities, detecting corrosion in buried metallic pipes and solving other problems of near-surface geophysics.

\section{Acknowledgements}

The author thanks the anonymous reviewer for useful comments that made it possible to improve the article presentation.

\section{ЛИТЕРАТУРА}

Abdelrahman E.M., El-Araby T.M., Ammar A.A., Hassanein H.I. A least-squares approach to shape determination from selfpotential anomalies. Pure and Applied Geophysics, V. 150, 1997, pp. 121-128. DOI: 10.1007/s000240050067.

Abdelrahman E.M., Sharafeldin S.M. A least squares approach to depth determination from residual self-potential anomalies caused by horizontal cylinders and spheres. Geophysics, V. 62, 1997, pp. 44-48.

Alizadeh A.M., Guliyev I.S., Kadirov F.A., Eppelbaum L.V. Geosciences in Azerbaijan. Volume II: Economic Minerals and Applied Geophysics. Springer. Heidelberg - N.Y., 2017, 340 p.

Babu R.H.V., Rao A.D. Inversion of self-potential anomalies in mineral exploration. Computers \& Geosciences, V. 14, No. 3, 1988, pp. 377-387.

Birch F. Imaging the water table by filtering self-potential profiles. Ground Water, V. 36, No. 5, 1998, pp. 779-782.

Bhattacharya B.B., Shalivakhan J.A., Bera A. Threedimensional probability tomography of self-potential anomalies of graphite and sulphide mineralization in Orissa and Rajasthan, India. First Break, V. 5, 2007, pp. 223-230.

Castermant J., Mendonca C., Revil A., Trolard F., Bourrie G., Linde N. Redox potential distribution inferred from self-potential measurements associated with the corrosion of a burden metallic body. Geophysical Prospecting, V. 56, No. 2, 2008, pp. 269-282.

Corry C.E. Spontaneous polarization associated with porphyry sulfide mineralization. Geophysics, V. 50, No. 6, 1985, pp. 1020-1034.

Cowan D.R., Allchurch P.D., Omnes G. An integrated geoelectrical survey on the Nangaroo copper-zinc prospect, near Leonora, Western Australia. Geoexploration, V. 13, 1975, pp. 77-98.

Dmitriev A.N. Direct and inverse SP modeling on the basis of exact model of self-potential field nature. Geology and Gephysics, V. 53, No. 6, 2012, pp. 797-812.

Drahor M.G. Application of the self-potential method to archaeological prospection: some case histories. Archaeological Prospection, V. 11, 2004, pp. 77-105.

El-Araby H.M. A new method for complete quantitative interpretation of self-potential anomalies. Journal of Applied Geophysics, V. 55, 2004, pp. 211-224.

Eppelbaum L.V. Revealing of subterranean karst using modern analysis of potential and quasi-potential fields. Proceedings of the 2007 SAGEEP Conference, V. 20, Denver, USA, 2007, pp. 797-810.

Eppelbaum L.V. Quantitative interpretation of magnetic anomalies from bodies approximated by thick bed models in complex environments. Environmental Earth Sciences, V. 74, 2015, pp. 5971-5988.

Eppelbaum L.V. Geophysical potential fields: geological and environmental applications. Elsevier. Amsterdam - N.Y., 2019, 465 p. 
of the 2007 SAGEEP Conference, V. 20, Denver, USA, 2007, pp. 797-810.

Eppelbaum L.V. Quantitative interpretation of magnetic anomalies from bodies approximated by thick bed models in complex environments. Environmental Earth Sciences, V. 74, 2015, pp. 5971-5988.

Eppelbaum L.V. Geophysical potential fields: geological and environmental applications. Elsevier. Amsterdam - N.Y., 2019, $465 \mathrm{p}$.

Eppelbaum L., Ben-Avraham Z., Itkis S. Ancient Roman remains in Israel provide a challenge for physicalarchaeological modeling techniques. First Break, V. 21, No. 2, 2003, pp. 51-61.

Eppelbaum L., Ben-Avraham Z., Itkis S., Kouznetsov S. First results of self-potential method application at archaeological sites in Israel. Transactions of the XI EUG International Symposium. Strasbourg, France, 2001, pp. 657.

Eppelbaum L.V., Itkis S.E., Khesin B.E. Optimization of magnetic investigations in the archaeological sites in Israel. In: Special Issue of Prospezioni Archeologiche "Filtering, Modeling and Interpretation of Geophysical Fields at Archaeological Objects", 2000, pp. 65-92.

Eppelbaum L.V. and Khesin B.E. Some common aspects of magnetic, induced polarization and self-potential anomalies interpretation: implication for ore target localization. Collection of Selected Papers of the IV Intern. Symp. on Problems of Eastern Mediterranean Geology, 2002, pp. 279-293.

Eppelbaum L.V., Khesin B.E. Advanced 3-D modelling of gravity field unmasks reserves of a pyrite-polymetallic deposit: A case study from the Greater Caucasus. First Break, V. 22, No. 11, 2004, pp. 53-56.

Eppelbaum L.V., Khesin B.E. Geophysical studies in the Caucasus. Springer. Heidelberg - N.Y., 2012, 411 p.

Eppelbaum L.V., Khesin B.E., Itkis S.E. Prompt magnetic investigations of archaeological remains in areas of infrastructure development: Israeli experience. Archaeological Prospection, V. 8, No. 3, 2001, pp. 163-185.

Eppelbaum L.V., Mishne A.R. Unmanned airborne magnetic and VLF investigations: effective geophysical methodology of the near future. Positioning, V. 2, No. 3, 2011, pp. 112-133.

Ernstson K., Scherer V. Self-potential variations with time and their relation to hydrogeologic and meteorological parameters. Geophysics, V. 51, No. 10, 1986, pp. 1967-1977.

Essa K., Mehanee S., Smith P.D. A new inversion algorithm for estimating the best fitting parameters of some geometrically simple body to measured self-potential anomalies. Exploration Geophysics, V. 39, No. 3, 2008, pp. 155-163.

Fitterman D.V. Calculation of self-potential anomalies near vertical contacts. Geophysics, V. 44, No. 2, 1979, pp. 195-205.

Fox R.W. On the electromagnetic properties of metalliferous veins in the mines of Cornwall. Royal Society, London, Philosophical Transactions, 1830, pp. 399-414.

Gobashy M., Abdelazeem M., Abdrabou M., Khalil M.H. Estimating model parameters from self-potential anomaly of $2 \mathrm{D}$ inclined sheet using whale optimization algorithm: Applications to mineral exploration and tracing shear zones. Natural Resources Research, https://DOI.org/10.1007/s11053-019-095260, 2019, pp.1-21.

Göktürkler G., Balkaya Ç. Inversion of self-potential anomalies caused by simple-geometry bodies using global optimization algorithms. Journal of Geophysics and Engineering, V. 10, No. 5, 2012, pp. 498-507.

Jardani A., Revil A., Santos F., Fauchard C., Dupont J. Detection of preferential infiltration pathways in sinkholes using joint inversion of self-potential and EM-34 conductivity data. Geophysical Prospecting, V. 55, No. 5, 2007, pp. 749-760.

Khesin B.E., Alexeyev V.V., Eppelbaum L.V. Interpretation of Geophysical Fields in Complicated Environments. Kluwer
Eppelbaum L., Ben-Avraham Z., Itkis S. Ancient Roman remains in Israel provide a challenge for physicalarchaeological modeling techniques. First Break, V. 21, No. 2, 2003, pp. 51-61.

Eppelbaum L., Ben-Avraham Z., Itkis S., Kouznetsov S. First results of self-potential method application at archaeological sites in Israel. Transactions of the XI EUG International Symposium. Strasbourg, France, 2001, pp. 657.

Eppelbaum L.V., Itkis S.E., Khesin B.E. Optimization of magnetic investigations in the archaeological sites in Israel. In: Special Issue of Prospezioni Archeologiche "Filtering, Modeling and Interpretation of Geophysical Fields at Archaeological Objects", 2000, pp. 65-92.

Eppelbaum L.V. and Khesin B.E. Some common aspects of magnetic, induced polarization and self-potential anomalies interpretation: implication for ore target localization. Collection of Selected Papers of the IV Intern. Symp. on Problems of Eastern Mediterranean Geology, 2002, pp. 279-293.

Eppelbaum L.V., Khesin B.E. Advanced 3-D modelling of gravity field unmasks reserves of a pyrite-polymetallic deposit: A case study from the Greater Caucasus. First Break, V. 22, No. 11, 2004, pp. 53-56.

Eppelbaum L.V., Khesin B.E. Geophysical studies in the Caucasus. Springer. Heidelberg - N.Y., 2012, 411 p.

Eppelbaum L.V., Khesin B.E., Itkis S.E. Prompt magnetic investigations of archaeological remains in areas of infrastructure development: Israeli experience. Archaeological Prospection, V. 8, No. 3, 2001, pp. 163-185.

Eppelbaum L.V., Mishne A.R. Unmanned airborne magnetic and VLF investigations: effective geophysical methodology of the near future. Positioning, V. 2, No. 3, 2011, pp. 112-133.

Ernstson K., Scherer V. Self-potential variations with time and their relation to hydrogeologic and meteorological parameters. Geophysics, V. 51, No. 10, 1986, pp. 1967-1977.

Essa K., Mehanee S., Smith P.D. A new inversion algorithm for estimating the best fitting parameters of some geometrically simple body to measured self-potential anomalies. Exploration Geophysics, V. 39, No. 3, 2008, pp. 155-163.

Fitterman D.V. Calculation of self-potential anomalies near vertical contacts. Geophysics, V. 44, No. 2, 1979, pp. 195-205.

Fox R.W. On the electromagnetic properties of metalliferous veins in the mines of Cornwall. Royal Society, London, Philosophical Transactions, 1830, pp. 399-414.

Gobashy M., Abdelazeem M., Abdrabou M., Khalil M.H. Estimating model parameters from self-potential anomaly of 2D inclined sheet using whale optimization algorithm: Applications to mineral exploration and tracing shear zones. Natural Resources Research, https://DOI.org/10.1007/s11053-01909526-0, 2019, pp.1-21.

Göktürkler G., Balkaya Ç. Inversion of self-potential anomalies caused by simple-geometry bodies using global optimization algorithms. Journal of Geophysics and Engineering, V. 10, No. 5, 2012, pp. 498-507.

Jardani A., Revil A., Santos F., Fauchard C., Dupont J. Detection of preferential infiltration pathways in sinkholes using joint inversion of self-potential and EM-34 conductivity data. Geophysical Prospecting, V. 55, No. 5, 2007, pp. 749-760.

Khesin B.E., Alexeyev V.V., Eppelbaum L.V. Interpretation of Geophysical Fields in Complicated Environments. Kluwer Academic Publishers (Springer). Ser.: Modern Approaches in Geophysics, Boston - Dordrecht - London, 1996, 368 p.

Kilty K.T. On the origin and interpretation of self-potential anomalies. Geophysical Prospecting, V. 32, No.1, 1984, pp. 51-62.

Lile O.B. Self potential anomaly over a sulphide conductor tested for use as a current source. Journal of Applied Geophysics, V. 36, No. 2-3, 1996, pp. 97-104. 


\title{
Geology and geophysics
}

Academic Publishers (Springer). Ser.: Modern Approaches in Geophysics, Boston - Dordrecht - London, 1996, 368 p.

Kilty K.T. On the origin and interpretation of self-potential anomalies. Geophysical Prospecting, V. 32, No.1, 1984, pp. 51-62.

Lile O.B. Self potential anomaly over a sulphide conductor tested for use as a current source. Journal of Applied Geophysics, V. 36, No. 2-3, 1996, pp. 97-104.

Logn O., Bolviken B. Self potentials at the Joma pyrite deposit, Norway. Geoexploration, V. 12, 1974, pp. 11-28.

Mendonca C.A. Forward and inverse self-potential modeling in mineral exploration. Geophysics, V. 73, No. 1, 2008, pp. F33-F43.

Murty B.V., Haricharan P. A simple approach toward interpretation SP anomaly due to 2-D sheet model of short dipole length. Geophysical Research Bulletin, V. 22, No. 4, 1984, pp. 213-218.

Nayak P.N. Electromechanical potential in surveys for sulphide. Geoexploration, V. 18, 1981, pp. 311-320.

Oliveti I., Cardarelli E. Self-Potential Data inversion for environmental and hydrogeological investigations. Pure and Applied Geophysics, V. 176, No. 8, 2019, pp. 3607-3628.

Parasnis D.S. Principles of Applied Geophysics. $4^{\text {th }}$ ed., revised and supplemented. Chapman \& Hall. London, 1986, 402 p.

Petrovsky A. The problem of a hidden polarized sphere. Philosophical Magazine, Ser. 7, V. 5, 1928, pp. 334-353, 914-933.

Rittgers J.B., Revil A., Karaoulis M., Mooney M.A., Slater L.D. Atekwana E.A. Self-potential signals generated by the corrosion of buried metallic objects with application to contaminant plumes. Geophysics, V. 78, No. 5, 2013, pp. EN65-EN82.

Quarto R., Schiavone D. Detection of cavities by the self-potential method. First Break, V. 14, No. 11, 1996, pp. 419-430.

Semenov A.S. Electric Prospecting by Self-Potential Method, $4^{\text {st }}$ ed., revised and supplemented. Nedra. Leningrad, 1980, 446 p. (in Russian).

Shevnin V.A. Identification of self-potential anomalies of a diffusion-absorption origin. Moscow University Geology Bulletin, V. 73, No. 3, 2018, pp. 306-311 (in Russian).

Shevnin V.A., Bobachev A.A., Ivanova S.V., Baranchuk K.I. Joint analysis of self potential and electrical resistivity tomography data for studying Alexandrovsky settlement. Transactions of the $20^{\text {th }}$ Meeting of Environmental and Engineering Geophysics. Athens, Greece, Mo PA2 04, 2014, pp. 1-5.

Tarkhov A.G. (Ed.). Electrical Prospecting. Geophysicist's Manual. Nedra. Moscow, 1980, 520 p. (in Russian).

Telford W.M., Geldart L.P., Sheriff R.E. Applied Geophysics, $2^{\text {nd }}$ edition. Cambridge University Press. Cambridge, 1990, 770 p.

Yüngül S. Spontaneous-potential survey of a copper deposit at Sariyer, Turkey. Geophysics, V. 19, No. 3, 1954, pp. 455-458.

Zaborovsky A.I. Electric Prospecting. Gostoptekhizdat. Moscow, 1963, 432 p. (in Russian).

Zhdanov M.S., Keller G.V. The Geoelectrical Methods in Geophysical Exploration. Elsevier. Amsterdam, 1994, 873 p.
Logn O., Bolviken B. Self potentials at the Joma pyrite deposit, Norway. Geoexploration, V. 12, 1974, pp. 11-28.

Mendonca C.A. Forward and inverse self-potential modeling in mineral exploration. Geophysics, V. 73, No. 1, 2008, pp. F33-F43.

Murty B.V., Haricharan P. A simple approach toward interpretation SP anomaly due to 2-D sheet model of short dipole length. Geophysical Research Bulletin, V. 22, No. 4, 1984, pp. 213-218.

Nayak P.N. Electromechanical potential in surveys for sulphide. Geoexploration, V. 18, 1981, pp. 311-320.

Oliveti I., Cardarelli E. Self-Potential Data inversion for environmental and hydrogeological investigations. Pure and Applied Geophysics, V. 176, No. 8, 2019, pp. 3607-3628.

Parasnis D.S. Principles of Applied Geophysics. $4^{\text {th }}$ ed., revised and supplemented. Chapman \& Hall. London, 1986, 402 p.

Petrovsky A. The problem of a hidden polarized sphere. Philosophical Magazine, Ser. 7, V. 5, 1928, pp. 334-353, 914-933.

Rittgers J.B., Revil A., Karaoulis M., Mooney M.A., Slater L.D., Atekwana E.A. Self-potential signals generated by the corrosion of buried metallic objects with application to contaminant plumes. Geophysics, V. 78, No. 5, 2013, pp. EN65-EN82.

Quarto R., Schiavone D. Detection of cavities by the self-potential method. First Break, V. 14, No. 11, 1996, pp. 419-430.

Shevnin V.A., Bobachev A.A., Ivanova S.V., Baranchuk K.I. Joint analysis of self potential and electrical resistivity tomography data for studying Alexandrovsky settlement. Transactions of the $20^{\text {th }}$ Meeting of Environmental and Engineering Geophysics. Athens, Greece, Mo PA2 04, 2014, pp. 1-5.

Telford W.M., Geldart L.P., Sheriff R.E. Applied Geophysics, $2^{\text {nd }}$ edition. Cambridge University Press. Cambridge, 1990, $770 \mathrm{p}$.

Yüngül S. Spontaneous-potential survey of a copper deposit at Sariyer, Turkey. Geophysics, V. 19, No. 3, 1954, pp. 455-458.

Zhdanov M.S., Keller G.V. The Geoelectrical Methods in Geophysical Exploration. Elsevier. Amsterdam, 1994, 873 p.

Бухникашвили А.В., Кебуладзе В.В., Табагуа Г.Г., Джаши Г.Г., Гугунава Г.Е., Татишвили О.В., Гогуа Р.А. Геофизическая разведка Аджарской группы медно-полиметаллических месторождений. Мецниереба. Тбилиси, 1974, 199 с.

Заборовский А.И. Электроразведка. Гостоптехиздат. Москва, 1963, $432 \mathrm{c}$.

Семенов А.С. Электроразведка методом естественного электрического поля. Недра. Ленинград, 1980, 446 с.

Тархов А.Г. (Ред.). Электроразведка. Справочник геофизика. Недра. Москва, 1980, 520 с.

Шевнин В.А. Выявление естественных электрических аномалий диффузионно-абсорбционного происхождения. Геологический Бюлл. МГУ, Т. 73, o. 3, 2018, с. 306-311.

Эппельбаум Л.В. Многомодельный подход к исследованию геофизических объектов. Депонировано в ВИНИТИ, Академия Наук ССCP, No. 7842-87, 1987, с. 1-10.

\section{УЛУЧШЕННЫЙ АНАЛИЗ АНОМАЛИЙ ЕСТЕСТВЕННОГО ЭЛЕКТРИЧЕСКОГО ПОЛЯ НА РУДНЫХ МЕСТОРОЖДЕНИЯХ ЮЖНОГО КАВКАЗА}

\author{
Эппельбаум Л.В. \\ Кафедра геофизики, Отделение наук о Земле, Факультет точных наук, \\ Тель-Авивский Университет, \\ 6997801, Рамат Авив, Тель-авив, Израиль: levap@post.tau.ac.il
}

Резюме. Метод естественного электрического поля (ЕЭП) - один из самых недорогих и технически несложных геофизических методов. Однако его применение ограничивает отсутствие надежной методологии интерпретации, в первую очередь для сложных геолого-геофизических условий. Обсуждены типичные помехи, возникающие в методе ЕЭП и пути их устранения. Краткий обзор имеющихся методов интерпретации свидетельствует об их недостаточной эффективности, особенно для сложных физико-геологических условий. Специальные количественные процедуры были разработаны для маг- 


\title{
L.V.Eppelbaum / ANAS Transactions, Earth Sciences 2 / 2019, 21-35; DOI: 10.33677/ggianas20190200029
}

нитного метода геофизической разведки в сложных условиях (наклонное намагничение, неровный рельеф местности и неизвестный уровень нормального поля). Проведенный анализ позволил выявить существенные общие особенности магнитного поля и ЕЭП. Эти общие аспекты позволяют применять к ЕЭП передовые методы интерпретации, разработанные в магниторазведке. Помимо надежного определения глубины аномального источника, эти методы позволяют внести поправки за наклонный поляризационный эффект и негоризонтальность линии наблюдений. Для классификации аномалий ЕЭП предложено рассчитывать новый параметр - 'естественный электрический момент'. Эти процедуры (улучшенные модификации методов особых точек и касательных) были успешно протестированы как на моделях ЕЭП, так и в реальных ситуациях на рудных месторождениях Турции и России. Наконец, разработанные интерпретационные процедуры были эффективно применены к нескольким рудным объектам Южного Кавказа (Филизчай и Кацдаг в Азербайджане и Учамбо в Грузии). Эффективность многомодельного подхода (с использованием гравитационного, магнитного и естественного электрического полей) продемонстрирована на обобщенной физико-геологической модели рудного объекта филизчайского типа. Полученные результаты указывают на большую практическую значимость разработанной методологии.

Ключевые слова: метод ЕЭП, помехи, количественный анализ, сложные физико-геологические условия, естественный электрический момент, рудные объекты

\section{CONUBİ QAFQAZIN FILIZ YATAQLARININ QUYU POTENSİALI ÜZRə MOLUMATLARIN TOKMILLOŞDIRILMIŞ ANALIZİ}

\author{
Eppelbaum L.V. \\ Geofizika kafedrası,Yer elmlari bölmasi, Daqiq Elmlar fakültəsi, Tel Aviv Universiteti \\ 6997801, Ramat Aviv, Tel Aviv, Israel: levap@post.tau.ac.il
}

Xülasə. Təbii elektrik sahəsi (TES) üsulu - ən ucuz və texniki cəhətdən qeyri-mürəkkəb geofiziki üsullardan biridir. Lakin onun tətbiqini etibarlı interpretasiya metodologiyasının, ilk növbədə mürəkkəb geoloji-geofiziki şərait üçün, olmaması məhdudlaşdırır. TES üsulunda yaranan tipik əngəllər və onların aradan qaldırılma yolları müzakirə edilmişdir. Mövcud interpretasiya üsullarının qısa xülasəsi onların, xüsusilə mürəkkəb fiziki-geoloji şərait üçün, kafi olmayan effektivliyini göstərir. Çətin şəraitdə (maili maqnitlə̧̧mə, ərazinin qeyri-düzgün relyefi və normal sahənin qeyri-məlum səviyyəsi) geofiziki kəşfiyyatın maqnit üsulu üçün xüsusi miqdari qayda işlənilmişdir. Aparılan təhlil maqnit sahəsi və TES-in mühüm ümumi xüsusiyyətlərini aşkar etməyə imkan vermişdir. Bu ümumi aspektlər maqnit kəşfiyyatında işlənib hazırlanmış qabaqcıl interpretasiya üsullarını TES-ə tətbiq etməyə imkan verir. Anomal mənbənin dərinliyinin etibarlı təyinindən əlavə, bu üsullar polyarizasiya effektinə və müşahidə xətlərinin qeyri-horizontallığına düzəlişlər verməyə inkan verir. TES-in anomaliyalarının təsnifatı üçün yeni parametrin - təbii elektrik momenti - hesablanması təklif edilmişdir. Bu qaydalar (xüsusi nöqtələr və toxunanlar üsullarının yaxşılaşdırılmış modifikasiyaları) həm TES modellərində, həm də Türkiyə və Rusiyanın filiz yataqlarında real situasiyalarda müvəffəqiyyətlə sınaqdan keçirilmişdir. Nəhayyət, işlənib hazırlanmış interpretasiya qaydaları Cənubi Qafqazın bir neçə filiz obyektlərində (Azərbaycanda Filizçay və Kaşdağ və Gürcüstanda Uçambo) effektiv tətbiq olunmuşdur. Çoxmodelli yanaşmanın effektivliyi (qravitasiya, maqnit və təbii elektrik sahələrindən istifadə etməklə) Filizçay tipli filiz obyektinin ümumiləşdirilmiş fiziki-geoloji modelində nümayiş etdirilmişdir. Alınan nəticələr işlənib hazırlanmış metodologiyanın böyük praktiki əhəmiyyətini göstərir.

Açar sözlər: TES üsulu, manealər, miqdari analiz, mürəkkab fiziki-geoloji şərait, təbii elektrik momenti, filiz obyektlari 